\title{
Reduced levels of stromal sex hormone-binding globulin and androgen receptor dysfunction in the sperm storage region of the rat epididymis
}

\author{
Fabiane de Santi ${ }^{1}$, Flávia L Beltrame ${ }^{1}$, Barry T Hinton², Paulo S Cerri ${ }^{3}$ and Estela Sasso-Cerri ${ }^{3}$ \\ ${ }^{1}$ Department of Morphology and Genetics, Federal University of São Paulo, São Paulo, Brazil, ${ }^{2}$ Department of Cell \\ Biology, University of Virginia, School of Medicine, Charlottesville, Virginia, USA and ${ }^{3}$ Department of Morphology, \\ Dental School of São Paulo State University, Araraquara, Brazil
}

Correspondence should be addressed to E Sasso-Cerri; Email: esasso@foar.unesp.br

\begin{abstract}
The cauda epididymidis is the major sperm storage region whose androgenic supply, essential for the sperm viability, is provided by the vasculature and is dependent upon testosterone diffusion through the stromal tissue to reach the epithelial cells. We have focused our efforts on examining the regulation of this important epididymal region by evaluating the impact of the androgen disrupter cimetidine on the epithelial-stromal androgenic microenvironment. Male rats received $100 \mathrm{mg} / \mathrm{kg}$ cimetidine (CMTG) or saline (CG) for 50 days, serum testosterone levels were measured and the epididymal cauda region was processed for light and transmission electron microscopy. In the proximal cauda region, the duct diameter was measured and birefringent collagen in the stroma was quantified. TUNEL-labeled epithelial cells were quantified, and androgen receptor (AR), karyopherin alpha (KPNA) and sex hormonebinding globulin (SHBG) levels were analyzed by immunofluorescence and Western blot. CMTG showed reduced duct diameter and high number of apoptotic epithelial cells. In the epithelium, the total AR concentration and the KPNA immunoreactivity were reduced, and a weak/absent AR nuclear immunofluorescence was observed in contrast to the enhanced AR immunolabeling observed in the cytoplasm of the epithelial cells. A significant reduction of collagen and SHBG levels in the stroma was also observed. Cimetidine treatment impairs AR nuclear import in the epithelium, causing androgenic dysfunction and subsequent epithelial cell apoptosis and duct atrophy. The connective tissue atrophy and reduction of SHBG stromal levels associated with epithelial androgenic dysfunction indicate a possible role of stromal SHBG in the androgenic supply of the sperm storage region of the epididymis.

Reproduction (2018) 152 467-479
\end{abstract}

\section{Introduction}

During the transit through the caput and corpus epididymidis, spermatozoa acquire progressive motility and the ability to fertilize an egg (Robaire \& Hinton 2002). When mature spermatozoa reach the cauda epididymidis, they are stored at a quiescent and viable state to maintain their motility and fertilizing ability before ejaculation (Cooper 1986, Robaire \& Hinton 2002). Maturation and storage processes depend upon a complex luminal fluid produced by the epididymal epithelial cells (Hinton \& Palladino 1995), which are highly dependent on androgens, mainly dihydrotestosterone (DHT) (Robaire \& Hamzeh 2011). Androgens regulate protein secretion (Moore \& Bedford 1979), water and ion resorption (Wong \& Yeung 1978, Wong et al. 1978) in the cauda epididymidis, which is essential in preventing premature sperm capacitation (Cooper 1986). Therefore, changes in the androgen levels impair epididymal epithelium structure and function, leading to alterations in the sperm storage microenvironment (Orgebin-Crist et al. 1975, Foldesy \& Bedford 1982, Robaire \& Hinton 2002) and male infertility (Robaire \& Hinton 2002).

Epididymal androgens are provided via luminal fluid from the testis and/or from the circulation (Robaire \& Hamzeh 2011). In these biological fluids, testosterone is bound to sex hormone-binding globulin (SHBG) (Hammond 2011, Robaire \& Hamzeh 2011), also called androgen-binding protein (ABP) which is produced and secreted from the same transcription unit of SHBG by Sertoli cells (Hammond 2011). In the proximal regions of the epididymis, SHBG, produced by Sertoli cells and bound to testosterone, is endocytosed by the principal cells (PCs) of the epididymal epithelium (Gueant et al. 1991, Hermo et al. 1998), leading to decrease in SHBG levels in the luminal fluid of the epididymal cauda region (Robaire \& Hamzeh 2011).

The general function proposed for SHBG in the blood is to regulate the bioavailability of steroid 
hormones. According to the free hormone hypothesis, only the free fraction of steroid hormone is able to diffuse from the vasculature to the target cells and, therefore, is biologically active (Mendel 1989, Laurent et al. 2016). However, androgen-dependent cells are often in a multicellular organ, in which they are compartmentalized and separated from the vasculature (Hammond 2016). Therefore, the free hormone hypothesis can explain how steroids act in cells that are in intimate contact with the vasculature; however, it is not clear how these hormones can reach more distant cells which are separated from the blood stream by stromal tissue and basement membrane (Hammond 2002, 2016). In more complex human tissues, where the steroid target cells are not in close contact with the blood vessels, such as the prostate (Sinnecker et al. 1988) and breast (Sinnecker et al. 1990), extravascular sequestration of SHBG has been observed. This protein has also been found in the stroma of the endometrium and epididymis from transgenic mice expressing human SHBG (Ng et al. 2006). The presence of SHBG in these complex tissues points to a function that goes beyond the simple regulation of the bioavailability of steroid hormones. This protein could be responsible for the transport of hormones from the blood across the stroma to the epithelium ( $\mathrm{Ng}$ et al. 2006).

In epididymal epithelial cells, testosterone is reduced by $5 \alpha$-reductase to DHT, the biologically active androgen in the epididymis, which is able to bind to the androgen receptor (AR) (Robaire \& Hamzeh 2011). AR is a nuclear steroid receptor that translocates to cell nuclei and acts as a transcription factor (Pratt \& Toft 1997, Bennett et al. 2010). In the absence of its ligand, the inactive AR is maintained in the cytoplasm, forming a heterocomplex (Pratt \& Toft 1997). When an agonist, for example DHT, binds to $A R$, a conformational change occurs and the receptor dissociates from the heterocomplex, exposing the nuclear localization signal (NSL) (Pratt \& Toft 1997, Bennett et al. 2010). Then, karyopherin alpha (KPNA), a nuclear import protein, binds to the AR NSL (Cutress et al. 2008) and subsequently forms a complex with karyopherin beta (KPNB) (Kumar et al. 2006). KPNB is responsible for the nuclear pore docking of the complex, in which RAN, a GTPase, mediates the translocation of AR to the nucleus (Chook \& Blobel 2001). Based on the fact that under androgen withdrawal, AR is maintained in the cytoplasm, studies have focused on the regulation of nucleocytoplasmic trafficking of $A R$ in an attempt to clarify how AR subcellular localization is regulated either in androgen-dependent cells or in castrationresistant cells, such as prostate cancer cells (Dar et al. 2014). Antiandrogens can act via different mechanisms (Georget et al. 2002); cyproterone acetate, for example, impairs the translocation of AR to the nucleus (Tezón et al. 1982, Tyagi et al. 2000), whereas flutamide allows the translocation of AR to nucleus, but interferes in the binding of AR to DNA (Farla et al. 2005, Lydka et al.
2011). Therefore, understanding the mechanisms of action of androgen or antiandrogens in this context has been clinically relevant (Dar et al. 2014).

Cimetidine is an $\mathrm{H}_{2}$ receptor antagonist that inhibits acid secretion by binding to these receptors in stomach parietal cells (Brogden et al. 1978). This drug also has anti-adhesion, antiangiogenic and immunomodulatory properties, making it usable as adjuvant therapy in the treatment of different types of cancers, such as gastric and colorectal (Kubecova et al. 2011). In male patients, cimetidine has caused hormonal changes (Wang et al. 1982), gynecomastia (Spence \& Celestin 1979) and a reduction in sperm concentration (Van Thiel et al. 1987). In kidney cells, prostate and pituitary, this drug interacts with $A R$ and antagonizes androgen action on androgen target tissues, indicating an antiandrogenic effect (Funder \& Mercer 1979, Winters et al. 1979, Knigge et al. 1983). In rats treated for long periods, this drug has caused testicular changes, such as reduction of the seminiferous epithelium due to apoptosis of germ cells and Sertoli cells (Sasso-Cerri \& Miraglia 2002, Sasso-Cerri \& Cerri 2008, Beltrame et al. 2011), and disorganization of peritubular tissue (França et al. 2000, Sasso-Cerri \& Cerri 2008). The treatment of rats with $100 \mathrm{mg} / \mathrm{kg}$ of cimetidine for a long period has caused reduction in serum testosterone levels (Beltrame et al. 2015) and in sperm concentration (Beltrame \& Sasso-Cerri 2016). This drug has also impaired the vas deferens structure associated with the reduction of AR immunoexpression in muscle cells (Koshimizu et al. 2013). Therefore, these data point to a potential effect of cimetidine as an androgen disrupter in the male reproductive system.

In contrast to other regions of the epididymis, the epithelial access to androgens in the cauda sperm storage region depends on the transport of hormones from the blood stream across the stroma to the epithelial cells. Therefore, we evaluated the impact of cimetidine on the cauda epididymidis androgenic microenvironment, focusing on the stromal SHBG levels and on the immunolocalization of AR and KPNA in the epithelium. The consequent effect of the treatment on the cauda epididymidis stromal and epithelial integrity was also evaluated.

\section{Materials and methods}

\section{Animal procedures}

The Ethical Committee for Animal Research of São Paulo Federal University (UNIFESP/EPM, Brazil) and the Ethical Committee for Animal Research of São Paulo State University (UNESP/FOAr) approved the protocol regarding the animal use and experimental procedures.

Twenty Holtzman 100-day-old male rats (Rattus norvegicus albinus) were maintained in polypropylene cages under $12 \mathrm{~h}$ light and $12 \mathrm{~h}$ darkness cycle at controlled temperature $\left(23 \pm 2^{\circ} \mathrm{C}\right)$, with water and food ad libitum. The animals were distributed into cimetidine (CMTG; $n=10$ ) and control (CG, 
$n=10)$ groups. CMTG received daily intraperitoneal injections of cimetidine (Hycimet, Hypofarma, Ribeirão das Neves, Brazil) $100 \mathrm{mg} / \mathrm{kg}$ of body weight (Beltrame et al. 2011, 2012, 2015, Koshimizu et al. 2013) and the CG received saline solution by the same route. The dosage used in this study $(100 \mathrm{mg} / \mathrm{kg}$ bw) was based on the therapeutic dose range of cimetidine usually administered to humans, which is $800-1200 \mathrm{mg} /$ day

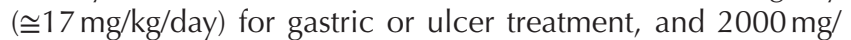
day $(\cong 28.5 \mathrm{mg} / \mathrm{kg} /$ day) for the treatment of Zollinger-Ellison syndrome (Brogden et al. 1978). Applying the BW ${ }^{3 / 4}$ scaling for the calculation of dosage to be applied to animal model (rats) (Epa 2006), the dosage used in this study $(100 \mathrm{mg} / \mathrm{kg})$ is equivalent, in humans, to $27.5 \mathrm{mg} / \mathrm{kg}$ (1920 mg/day). According to Brogden et al. (1978), doses of cimetidine below $2400 \mathrm{mg} /$ day, a therapeutic dosage, do not cause systemic toxicity.

All groups were treated for fifty consecutive days, which corresponds to the seminiferous epithelium cycle in the rat (Clermont et al. 1959), and induces testicular changes (França et al. 2000, Sasso-Cerri \& Miraglia 2002, Sasso-Cerri \& Cerri 2008, Beltrame et al. 2011, 2012, 2015). In patients, the clinical use of cimetidine is over a long period of time. For the treatment of ulcers, the period extends to $4-6$ weeks (Clayman 1977, Brogden et al. 1978) and 1-2 years for the treatment of cancer (Matsumoto et al. 2002).

After treatment, the animals were anesthetized with $80 \mathrm{mg} /$ kg BW of ketamine hydochloride (Francotar, Virbac do Brasil Ind. Com. Ltda, Jurubatuba, Brazil) and $8 \mathrm{mg} / \mathrm{kg}$ BW of xylazine hydrochloride (Virbaxyl; Virbac do Brasil Ind. Com. Ltda Jurubatuba, Brazil). The epididymides were weighed and the epididymal cauda region was removed, fixed for histological analyses or frozen at $-80^{\circ} \mathrm{C}$ for molecular analysis (Lim et al. 2011).

\section{Testosterone measurement}

Serum testosterone levels were determined at São Lucas Clinical Analysis Laboratory (Araraquara, SP, Brazil) by chemiluminescence immunoassay using Access 2 Immunoassay System (Beckman Coulter, Brea, CA, USA). The Access Testosterone Immunoassay kit (Beckman Coulter) was used and the analytical sensitivity was $10 \mathrm{ng} / \mathrm{dL}$.

\section{Histological procedures for light microscopy}

The cauda epididymides from six animals of each group were fixed for $48 \mathrm{~h}$ at room temperature in $4 \%$ formaldehyde buffered at $\mathrm{pH} 7.4$ with $0.1 \mathrm{M}$ sodium phosphate, dehydrated in ethanol and embedded in glycol methacrylate (historesin) or paraffin. Historesin sections were stained with H.E. (Cerri \& Sasso-Cerri 2003) for morphological analysis, and the paraffin sections were submitted to picrosirius staining, TUNEL method and immunofluorescence. All parameters were evaluated in the proximal region of the cauda epididymidis (Reid \& Cleland 1957, Robaire \& Hermo 1988), which corresponds to segments 15 and 16 (Domeniconi et al. 2016).

\section{Transmission electron microscopy (TEM)}

Epididymal tissue was fixed for $16 \mathrm{~h}$ in a mixture of freshly prepared $4 \%$ formaldehyde and 5\% glutaraldehyde buffered at $\mathrm{pH} 7.2$ with $0.1 \mathrm{M}$ sodium cacodylate. After washing in $0.1 \mathrm{M}$ sodium cacodylate at $\mathrm{pH} 7.2$, the tissue was transferred to sodium cacodylate-buffered $1 \%$ osmium tetroxide at $\mathrm{pH} 7.2$ for $1 \mathrm{~h}$. The tissue was then immersed in $2 \%$ aqueous uranyl acetate for $1.5 \mathrm{~h}$, dehydrated in graded concentrations of ethanol, treated with propylene oxide and then embedded in Araldite (Beltrame et al. 2012, 2015). Ultrathin sections were collected on grids, stained in alcoholic $2 \%$ uranyl acetate and lead citrate and examined in a transmission electron microscope (Tecnai G2 Spirit, FEI Company).

\section{Diameter of epididymal duct}

A DP-71 camera attached to Olympus BX-51 microscope and an Image-Pro Express 6.0 Olympus Image-Pro system were used to measure the diameter of the duct. In four non-serial H.E.-stained sections of the cauda epididymidis per animal, the diameters of duct profiles of the proximal regions were measured $(\mu \mathrm{m})$, totaling 52 duct profiles per animal.

\section{Analysis of birefringent collagen under polarized light}

Four non-serial sections per animal from CG and CMTG were stained using the picrosirius-red method and analyzed under polarized light (Olympus BX-51 microscope). In 10 fields of proximal region of the cauda epididymidis, totaling an area of approximately $92,000,000 \mu \mathrm{m}^{2}$, the area occupied by birefringent collagen was measured using Leica Application Suite software (LAS 4.3, Leica).

\section{TUNEL method and quantification of the number of TUNEL-positive cells}

The TUNEL method was performed as previously described (Sasso-Cerri \& Miraglia 2002, Beltrame et al. 2011, 2012) and following the ApopTag Peroxidase In Situ Kit (Millipore) manufacturer's instructions. After treatment with proteinase $\mathrm{K}$ (Sigma-Aldrich) and inactivation of endogenous peroxidase with hydrogen peroxide, the sections were treated with an equilibration buffer for $30 \mathrm{~min}$ at room temperature and incubated in terminal deoxynucleotidyl transferase (TdT) at $37^{\circ} \mathrm{C}$ for $1 \mathrm{~h}$. The sections were incubated in anti-digoxigeninperoxidase followed by $0.06 \% 3,3^{\prime}$-diaminobenzidine (DAB: Sigma-Aldrich) and counterstained with Carazzi's hematoxylin. Sections used as negative controls were processed in the same manner, except that they were incubated in a TdT-free solution.

In two non-serial epididymal sections per animal, the number of TUNEL-positive epithelial cells in the proximal region of the cauda epididymidis was quantified in a total standard epithelial perimeter of $18,000 \mu \mathrm{m}$. The number of TUNEL-positive epithelial cells/ $\mu \mathrm{m}$ of epithelial surface was obtained.

\section{$A R, K P N A$ and SHBG immunofluorescence}

For antigen recovery, the slides containing non-serial paraffin sections were immersed in $0.001 \mathrm{M}$ sodium citrate buffer $\mathrm{pH} 6.0$ and heated in a microwave oven at $90^{\circ} \mathrm{C}$ for $30 \mathrm{~min}$. The sections were incubated overnight with the 
following primary antibodies: rabbit anti-AR polyclonal antibody (1:150; Millipore, Temecula, USA; 06-680 PG-21), rabbit anti-SHBG polyclonal antibody (1:50; Santa Cruz Biotechnology; sc-32890) and rat anti-KPNA monoclonal antibody (1:100; Santa Cruz Biotechnology; sc-101540) in a humidified chamber at $4^{\circ} \mathrm{C}$. After washing in PBS, the sections were incubated at room temperature in the dark for $1 \mathrm{~h}$, respectively, with Alexa Fluor 594 anti-rabbit antibody (1:1000; Molecular Probes by Life Technologies), Alexa Fluor 498 anti-rabbit antibody (1:1000; Molecular Probes by Life Technologies) and FITC goat anti-rat antibody (1:100; Santa Cruz Biotechnology; sc-2011). In the latter case, the sections were incubated with goat serum for 30 min before incubation with secondary antibody to avoid unspecific binding of anti-rat secondary antibodies to the tissue (Nybo 2012). The sections were washed in PBS, and the nuclear staining was performed with DAPI (Molecular Probes by Life Technologies) for $5 \mathrm{~min}$ in the dark at room temperature. The slides were mounted with Fluoromount G mounting medium (EMS, Hatfield, USA). As negative controls, sections were incubated with non-immune serum in place of primary antibodies.

Sections of mouse cauda epididymidis as well as sections of rabbit and rat heart, which express high levels of KPNA (Tsuji et al. 1997), were used as positive controls to confirm the specificity of the antibodies. Sections of human cauda epididymidis and rat testis were also used to confirm the specificity of the SHBG immunoexpression.

\section{$A R, K P N A$ and SHBG immunofluorescent areas}

The analysis of the immunofluorescence was performed using a DFC 550 Camera (Leica) attached to a BM4000 B LED microscope (Leica), and the Leica Application Suite software (LAS 4.3, Leica).

The measurement of AR, KPNA and SHBG immunoexpression was performed in the proximal region of four non-serial sections of the cauda epididymidis per animal. In the AR and KPNA immunolabeled sections, a standardized total epithelial area of 50,000 $\mu^{2}$ was measured. In this area, the nuclear and cytoplasmic AR immunofluorescent areas as well as KPNA immunofluorescent area were measured, and the area per $\mu \mathrm{m}^{2}$ of epithelium was obtained. The AR immunofluorescent nuclear/ cytoplasmic ratio was also calculated. SHBG immunofluorescent area was measured in a standardized total connective tissue area of $560,000 \mu \mathrm{m}^{2}$ per animal, and the immunofluorescent area $/ \mu \mathrm{m}^{2}$ of connective tissue was calculated.

During each immunoreaction analyzed in the sections from CG and CMTG, all the parameters of the software, including threshold adjustment and color range - hue, saturation and intensity (LAS 4.3, Leica) - were rigorously calibrated/ standardized for each image analyzed.

\section{Total protein extraction}

Frozen cauda epididymidis regions from CG and CMTG epididymides were homogenized using lysis buffer $(50 \mathrm{mM}$ Tris $\mathrm{pH} 8.0,150 \mathrm{mM} \mathrm{NaCl}, 1 \mathrm{mM}$ EDTA, $10 \%$ glycerol, $1 \%$ Triton X-100, $1 \mathrm{mM}$ phenylmethylsulfonyl fluoride (PMSF)), containing $5 \mathrm{ng} / \mathrm{mL}$ of each of the following protease inhibitors:
Pepstatin, Leupeptin, Aprotinin, Antipain and Chymostatin (Sigma-Aldrich; P8340). After overnight incubation at $4^{\circ} \mathrm{C}$, the homogenates were centrifuged for $20 \mathrm{~min}$ at $8,944 \mathrm{~g}$ and $4^{\circ} \mathrm{C}$, and the supernatant was collected. Protein concentration was determined using Bradford assay (Sigma-Aldrich; B6916), and Western blot for SHBG detection was performed. Rat testis extract was used as positive control.

\section{Subcellular fractionation}

The extraction of nuclear and cytoplasmic proteins from the cauda epididymidis of CG and CMTG animals was performed following the instructions from the Nuclear Extraction Kit (Abcam; ab113474). Nuclear and cytoplasmic protein concentrations were measured using Bradford assay (SigmaAldrich; B6916) and Western blot for AR and actin detection was performed in both fractions.

\section{Western blot}

Protein samples were separated in 12\% SDS-PAGE and transferred to a nitrocellulose membrane (GE Healthcare). The membranes were treated for $1 \mathrm{~h}$ with blocking solution containing 5\% non-fat dry milk diluted in PBS/T (PBS/0.05\% Tween 20) for nonspecific blocking and incubated overnight at $4^{\circ} \mathrm{C}$ with the following primary antibodies: rabbit antiSHBG polyclonal antibody (1:200; Santa Cruz Biotechnology; sC-32890); rabbit anti-AR polyclonal antibody (1:800; Millipore; 06-680 PG-21) diluted in blocking solution. After washes in $\mathrm{PBS} / \mathrm{T}$, membranes were incubated with HRP conjugated antirabbit secondary antibody (1:7500; Sigma-Aldrich), diluted in blocking solution for $1 \mathrm{~h}$ at room temperature. The reactions were detected using enhanced chemiluminescence system (ECL). For positive controls, the membranes were stripped and incubated with rabbit anti-actin antibody (1:8000; SigmaAldrich). The assays were reproduced in triplicate for each group (CG and CMTG). The optical density values of protein bands were analyzed by optical densitometry using ImageJ (version 1.50i) analysis software (NIH), and protein levels were normalized to actin.

\section{Statistical analysis}

Statistical analysis was performed using GraphPad Prism 6.01 software. The data were analyzed by Student's $t$-test at a significance level of $P \leq 0.05$.

\section{Results}

\section{Serum testosterone levels and epididymal weight}

In CMTG, the serum testosterone levels and the epididymidis weight decreased significantly in comparison with CG (Fig. 1A and B).

\section{Morphological features and collagen content}

In animals from the CG, the proximal cauda epididymidis sections showed normal pseudostratified epithelium 

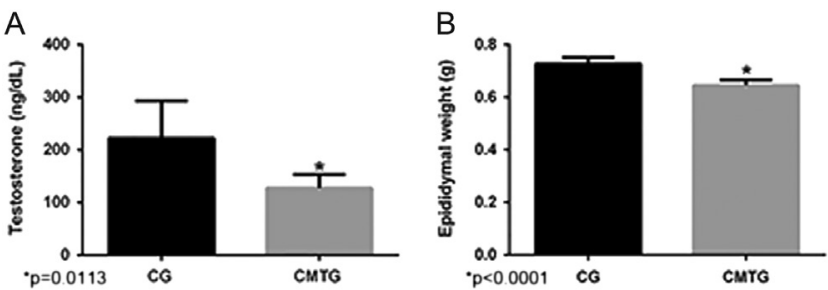

Figure 1(A and B) Serum testosterone levels (A) and the weights of epididymides (B) were significantly reduced in CMTG.

(Fig. 2A, C and E), in which PCs, clear cells and basal cells (BCs) were observed (Fig. 2C and E). A welldefined fibrous muscular layer surrounding the epithelia and a vascularized loose connective tissue among the duct profiles were observed (Fig. 2A and C). However, in epididymal sections of animals from the CMTG, the duct profiles showed irregular shape and reduced diameter (Fig. 2B) compared to CG (Fig. 2A). Epithelial cells showing small nucleus with strongly basophilic and condensed chromatin were found (Figs 2D, F and 3G). The morphometric analysis showed a significant reduction in the duct diameter compared to CG (Fig. $2 \mathrm{H}$ ).

In H.E.- (Fig. 2A, B, C and D, and picrosirius- (Fig. 3A and $\mathrm{B}$ ) stained sections, a reduction in the connective tissue stroma was observed in the proximal cauda epididymidis of animals from the CMTG (Figs 2B, D and $3 \mathrm{~B})$. In this group, the area occupied by birefringent collagen in the connective tissue was reduced significantly (45\%) when compared to the CG (Fig. 3C).

\section{TUNEL-positive epithelial cells and apoptotic features}

In the CG, scarce TUNEL-labeled cells were found in the epididymal epithelium (Fig. 4A), whereas in the CMTG animals, numerous TUNEL-positive epithelial cells were observed (Fig. 4B, C, D, E and F). This finding was confirmed by the quantitative analyses in which a highly significant increase in the number of TUNEL-positive epithelial cells was observed in the CMTG compared to the CG (Fig. 4I). TUNEL-positive structures were not found in negative controls (data not shown). TEM showed epithelial cells having an irregular-shaped nucleus and electron dense masses of condensed chromatin in the nuclear periphery from CMTG animals (Fig. 4H) in comparison to the normal aspect of the cells in CG (Fig. 4G).

\section{Detection of $A R$}

In the proximal cauda epididymidis region of animals from the CG, strong AR immunofluorescence was observed in the nuclei of PCs, BCs and fibroblasts (Fig. 5A, B, C and D). However, in the CMTG, a diffuse AR immunofluorescence was observed in the cytoplasm of PCs, while the nuclei of these cells showed a weak or no AR immunofluorescence (Fig. 5F, G and H).
Immunolabeled structures were not observed in negative controls for detection of AR (data not shown).

The AR immunofluorescent nuclear area decreased in CMTG, whereas the AR immunofluorescent cytoplasmic area increased in this group when compared with CG; thus, the AR immunofluorescent nuclear/cytoplasmic ratio decreased significantly (86\%) in CMTG when compared with CG (Fig. 5I).

The optical densitometry of the Western blot analysis revealed that the total $A R$ concentration in the cauda epididymidis decreased in CMTG (Fig. 5J). The analysis of the subcellular fractions showed high levels of $A R$ in the nuclear extract, while a weak signal was found in the

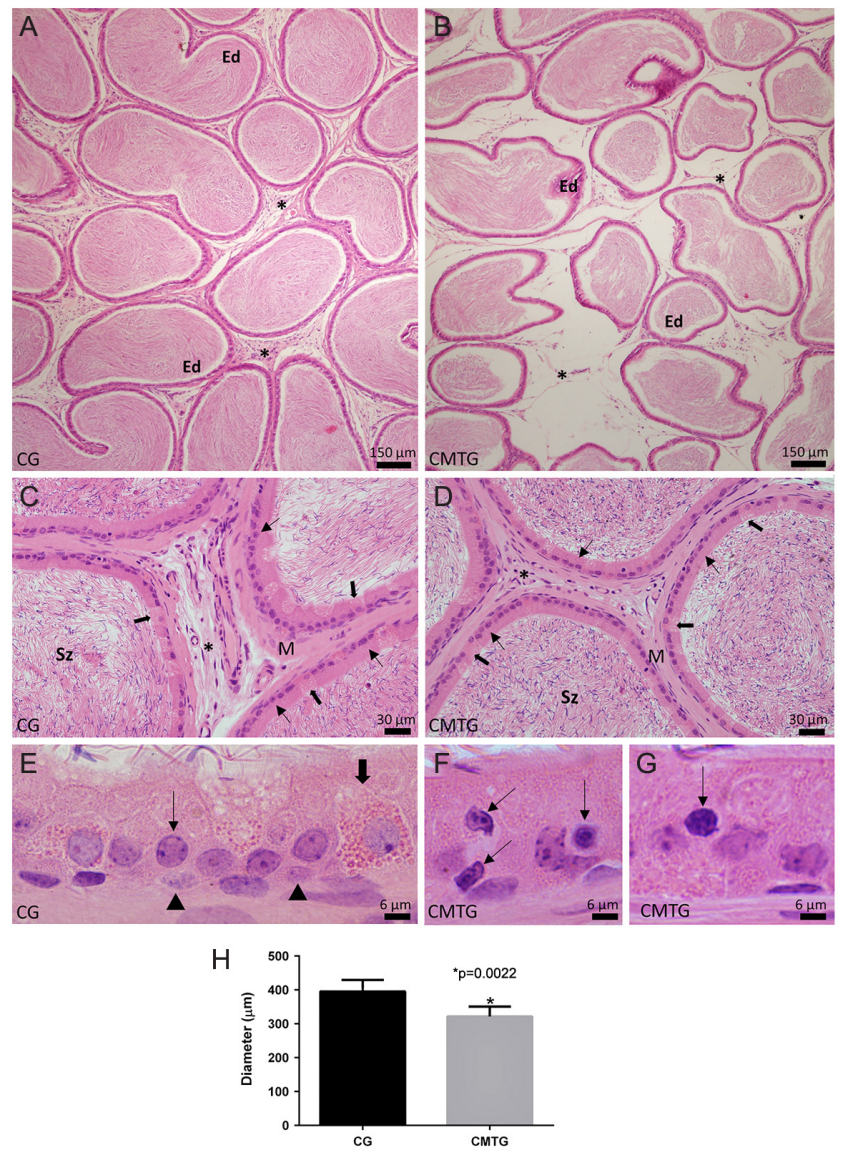

Figure 2 (A, B, C, D, E, F and G) Photomicrographs of proximal cauda epididymidis region sections of animals from CG (A, C and $E$ ) and CMTG (B, D, F and G) stained with H.E. In (A) and (B), epididymal duct profiles (Ed) and connective tissue $\left({ }^{*}\right)$ stroma among the ducts are observed. Note that in in CMTG, the epididymal duct sections show irregular shape and reduced diameter (B). The connective tissue stroma is also reduced $(B$ and $D)$ in comparison to CG (A and C). In (C, D and E), principal (thin arrows), clear (thick arrows) and basal (arrowheads) cells are observed in the epithelium. In comparison with CG $(\mathrm{E})$, note that in $(\mathrm{F})$ and $(\mathrm{G})$, some epithelial cell nuclei are smaller and show strongly basophilic and condensed chromatin (thin arrows). Spermatozoa (Sz); fibro muscular layer (M). (H) Epididymal duct diameter of animals from CMTG is significantly reduced compared to CG. 

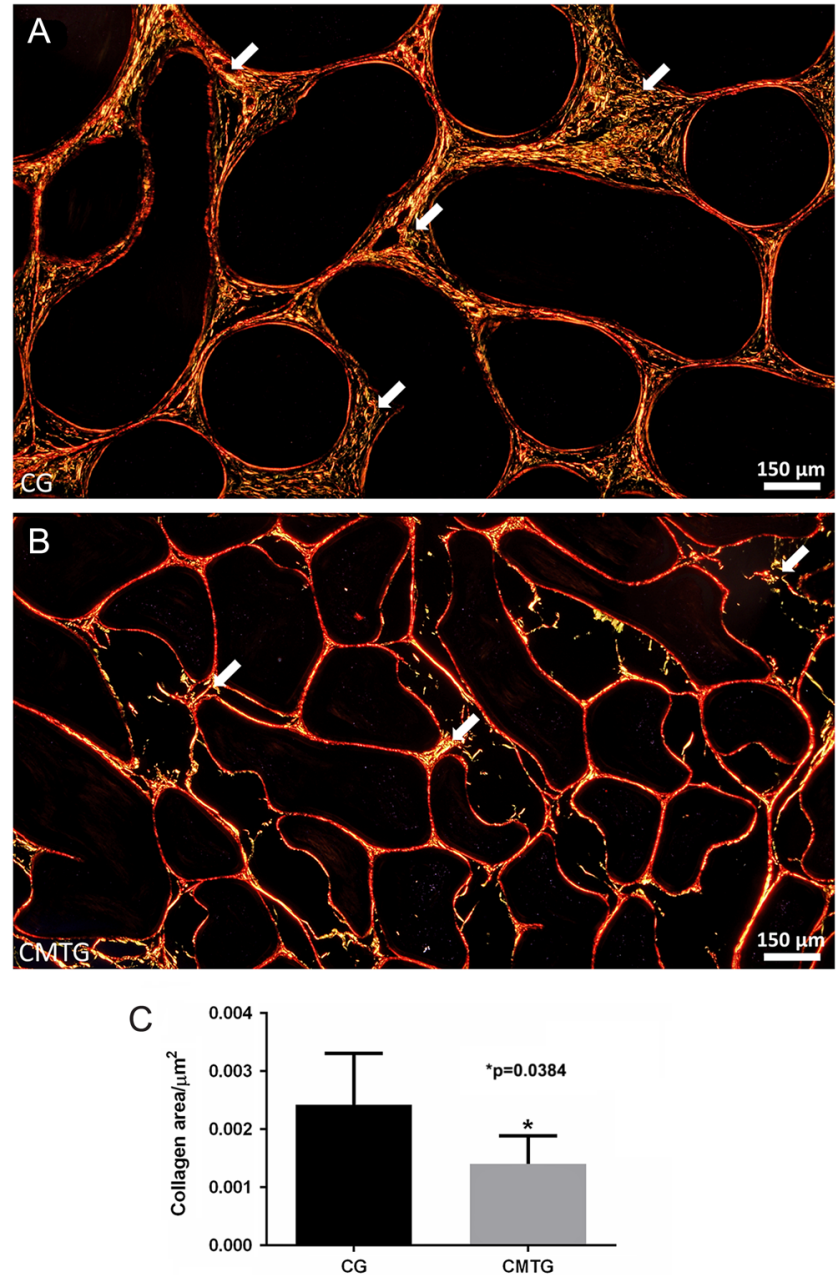

Figure 3 ( $A$ and B) Photomicrographs of cauda epididymidis sections stained with picrosirius and analyzed under polarized light. In (B), the connective tissue shows reduced birefringent collagen content (arrows) compared to (A). (C) The birefringent collagen area of connective tissue stroma is significantly reduced in CMTG compared to CG.

cytoplasmic extract of CG. In samples from the CMTG, a strong AR signal was detected in the cytoplasmic extract compared to a weak signal in the nuclear extract. The optical densitometry of protein levels confirmed the differences between the groups. In both groups, a strong actin signal was only detected in the cytoplasmic extracts, confirming the purity of the cytoplasmic and nuclear fractions (Fig. 5K).

\section{Detection of KPNA}

In the cauda epididymidis epithelial cells of animals from the CG, strong KPNA immunofluorescence was observed in the cytoplasm, mainly in the perinuclear area (Fig. 6A, B and C), whereas in CMTG, a diffuse and weak cytoplasmic KPNA immunofluorescence was seen in the epithelial cells (Fig. 6E and F). In the sections used as negative control, immunofluorescence
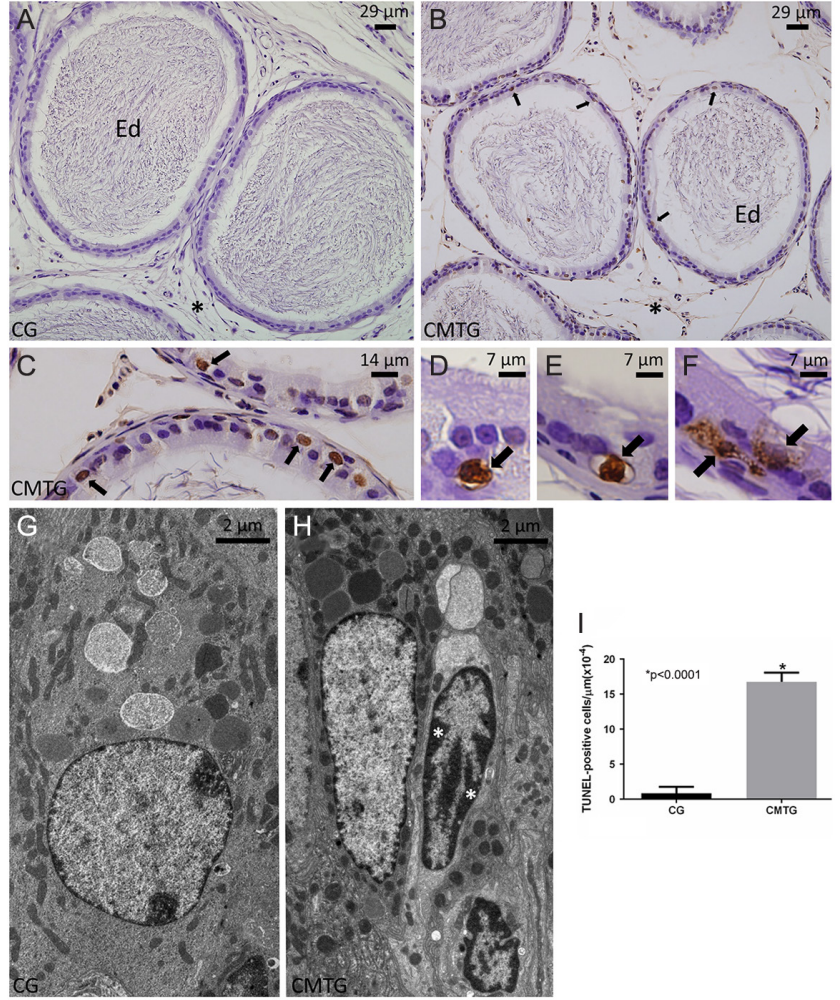

Figure $4(A, B, C, D, E$ and F) Photomicrographs of proximal cauda epididymidis region sections of animals from CG (A) and CMTG (B, $\mathrm{C}, \mathrm{D}, \mathrm{E}$ and $\mathrm{F}$ ) showing TUNEL localization. In (B, C, D, E and F), numerous TUNEL-positive epithelial cells (arrows) are observed in CMTG when compared to CG (A). Epididymal duct profile (Ed); connective tissue $\left(^{*}\right)$. (G and $\mathrm{H}$ ) Electron micrograph of cauda epididymal epithelial cells of animals from CG (G) and CMTG (H). In $(\mathrm{H})$, an abnormal cell showing irregular-shaped nucleus and electron dense masses of chromatin in the nuclear periphery (asterisks) is observed. (I) Significant increase in the number of TUNEL-positive cells in the cauda epididymal epithelium of animals from the CMTG is observed compared to CG.

was not observed (Fig. 6G). However, in mouse cauda epididymidis sections, the KPNA immunofluorescence pattern in the epithelium was similar to that observed in the epithelium of rat epididymal sections from CG (Fig. 6H). An intense immunofluorescence was also observed in rat and rabbit heart cross sections (Fig. 6I and J), confirming the specificity of the antibody.

The morphometric analysis showed that KPNA immunofluorescent epithelial area was reduced significantly (78\%) in CMTG compared to CG (Fig. 6K).

\section{Detection of SHBG}

An enhanced SHBG immunofluorescence was observed in the connective tissue of the proximal cauda region from the CG (Fig. 7A, B and C), whereas a scarce SHBG immunofluorescent connective tissue was observed in animals from the CMTG (Fig. 7D, E and F). A strong immunolabeling was also observed in the connective 

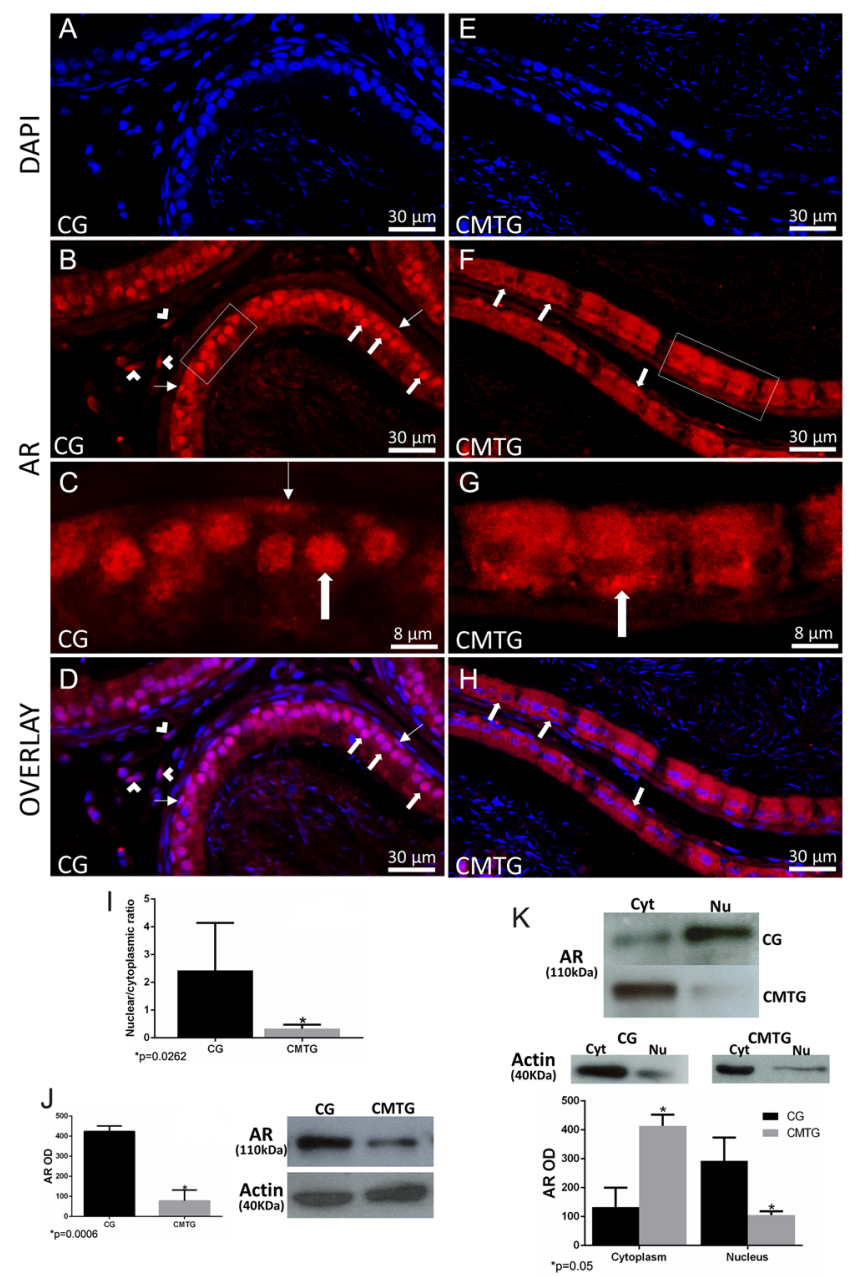

Figure 5 (A, B, C, D, E, F, G and H) Photomicrographs of proximal cauda epididymidis region sections showing $A R$ immunofluorescence in CG (B, C and D) and CMTG (F, G and H). In (A) and (E), DAPI nuclear immunofluorescence. In (B, $C$ (high magnification of $B$ ) and (D)), strong AR immunolabeling is observed in the nuclei of principal cells (thick arrows), basal cells (thin arrows) and fibroblasts (arrowheads), whereas the cytoplasm shows a weak or absent immunolabeling. In (F, G (high magnification of $F$ ) and $(H)$ ), principal cells show diffuse AR immunolabeling in the cytoplasm (thick arrows) and weak or negative AR immunolabeling in the nuclei. (I) The AR immunofluorescent nuclear/cytoplasmic ratio is reduced in CMTG. (J) Total AR optical density (AR OD) of Western blot shows low levels of AR in the cauda epididymidis of CMTG. (K) Western blot analysis of AR levels in cauda epididymidis cytoplasmic (Cyt) and nuclear (Nu) extracts. Strong bands at $110 \mathrm{kDa}$, corresponding to the AR molecular weight, are detected in the nuclear fraction of CG and cytoplasmic fraction of CMTG. AR optical density (AR OD) shows increased AR levels in the cytoplasm and low AR levels in the nucleus of CMTG when compared to CG. Actin signal is observed in the cytoplasmic fraction of both groups.

tissue of the human epididymal cauda, similar to the rat epididymis of CG (Fig. 7G). In the rat testicular sections, strong immunofluorescence was observed in the Sertoli cells (Fig. 7H). In the sections used as negative controls, immunofluorescence was not observed (data not shown).
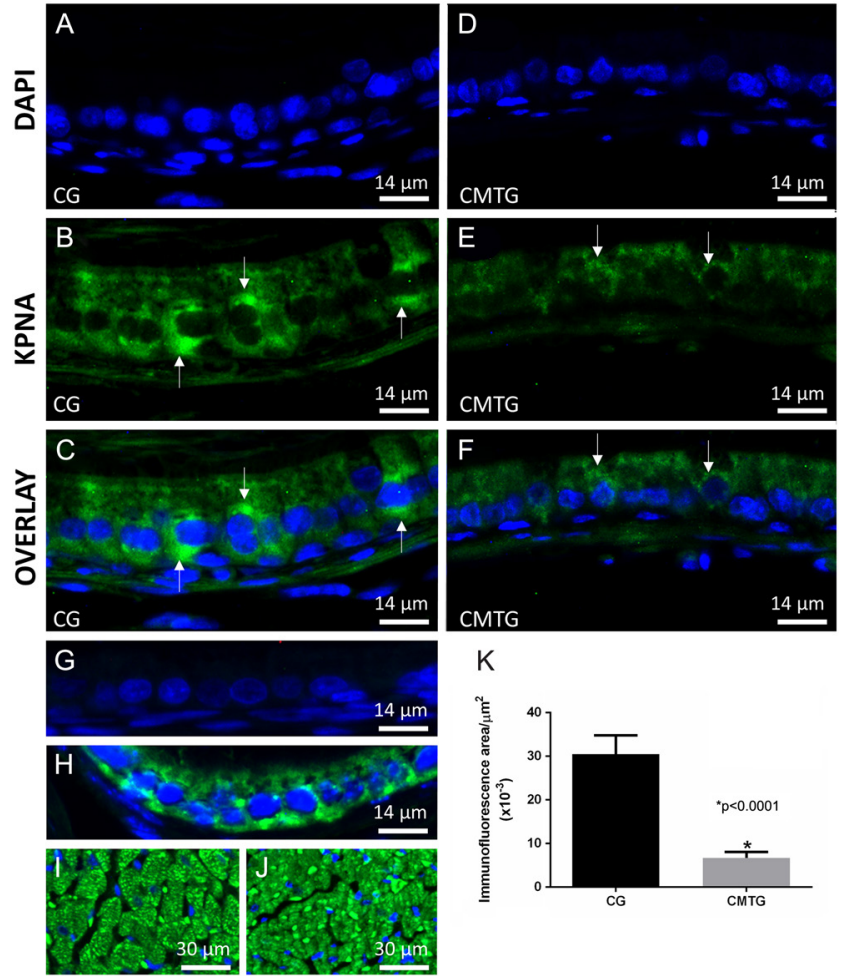

$\mathrm{K}$

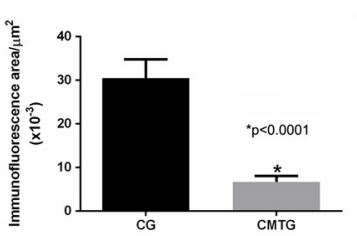

Figure 6 (A, B, C, D, E, F, G, H, I and J) Photomicrographs of cauda epididymidis sections from CG (B and C) and CMTG (E and F) showing immunofluorescence of karyopherin alpha (KPNA). In (A) and (D), DAPI nuclear labeling. Negative $(G)$ and positive $(\mathrm{H}, \mathrm{I}$ and $\mathrm{J})$ controls are shown. In (B) and (C), an enhanced perinuclear immunolabeling is observed in the epithelial cells of CG (thin arrows) in contrast to weak KPNA immunofluorescence shown in CMTG (E and $F$; thin arrows). In (G), immunofluorescence is not observed in the section of the rat cauda used as negative control. In $(\mathrm{H})$, section of mouse cauda (positive control) showing similar immunoexpression pattern to CG. In (I and J), cross sections of rat and rabbit heart, respectively, used as positive controls, show enhanced KPNA immunoreactivity. (K) A significant reduction in the KPNA immunofluorescence area per $\mu \mathrm{m}^{2}$ of the cauda epididymal epithelium is observed in CMTG compared to CG.

In CMTG, the SHBG immunofluorescent area reduced significantly $(71 \%)$ compared to the CG (Fig. 7I). Western blot analysis showed a weak signal for SHBG in CMTG when compared to CG, as confirmed by the optical densitometry (Fig. 7J). A strong SHBG signal was observed in the rat testis extract (Fig. 7J).

\section{Discussion}

Cimetidine has caused sexual disorders in male patients (Spence \& Celestin 1979, Wang et al. 1982, Van Thiel et al. 1987) and has demonstrated a competitive action with testosterone by AR in kidney cells (Funder \& Mercer 1979), hypophysis (Knigge et al. 1983) and prostate (Winters et al. 1979), indicating that this drug exerts an antiandrogenic effect. In male rats, cimetidine has caused decrease in the serum testosterone levels 

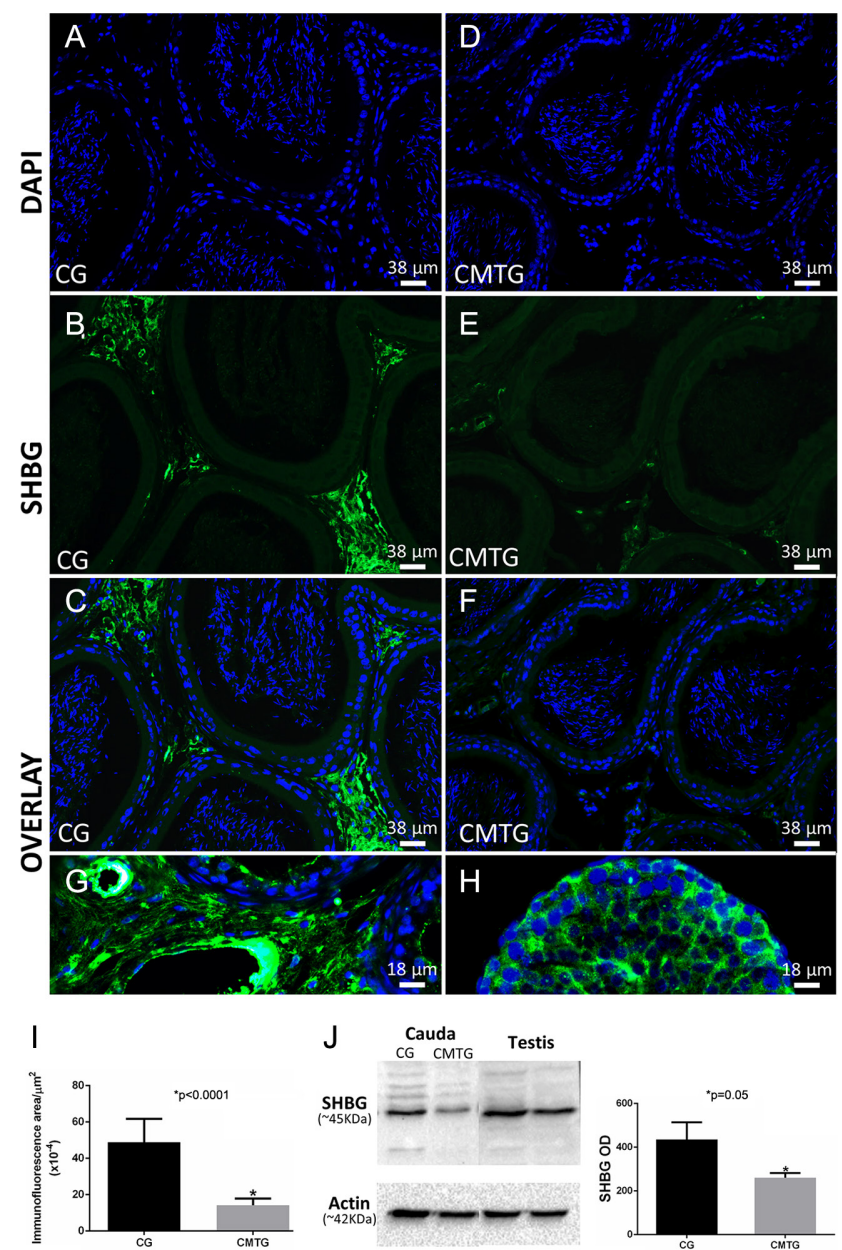

Figure 7 ( A, B, C, D, E, F, G and H) Photomicrographs of cauda epididymidis sections showing immunofluorescence of SHBG in CG (B and $\mathrm{C}$ ) and CMTG (E and F). (A) and (D) show DAPI nuclear labeling. In (B) and (C), the connective tissue shows an enhanced SHBG immunelabeling, while in $(\mathrm{E})$ and $(\mathrm{F})$, a weak immunofluorescence is observed. In $(\mathrm{G}$ and $\mathrm{H})$, sections of human cauda epididymidis $(\mathrm{G})$ and rat testis $(\mathrm{H})$ used as positive controls. Similar to CG, SHBG immunofluorescence is also observed in the connective tissue stroma of the human cauda epididymidis $(\mathrm{G})$. In rat testis, Sertoli cells are positive for SHBG (H). (I) A significant reduction in the SHBG immunofluorescence area per $\mu \mathrm{m}^{2}$ of connective tissue is observed in CMTG compared to CG. (J) Western blot analysis of SHBG in the total cauda epididymidis and testis extract. Strong bands at $45 \mathrm{kDa}$, corresponding to SHBG molecular weight, are observed in the testicular extract (positive control) and in the cauda epididymidis extract of CG when compared to the weak band in CMTG. SHBG optical density (SHBG OD) shows low SHBG levels in CMTG when compared to CG. Actin bands are observed in both extracts.

due to Leydig cell apoptosis (Beltrame et al. 2015) as well as reduction in the testosterone release by pig Leydig cells in vitro (Goda et al. 2017). Reduction in the sperm concentration (Beltrame \& Sasso-Cerri 2016) together with structural and functional disorders in the testes (França et al. 2000, Sasso-Cerri \& Miraglia 2002, Sasso-Cerri \& Cerri 2008, Beltrame et al. 2011, 2012,
2015) and vas deferens (Koshimizu et al. 2013) have also been caused by cimetidine, indicating that this drug acts as an androgen disrupter in the male reproductive system. In the present study, in addition to the reduction in the testosterone levels, cimetidine impaired the epididymal sperm storage region histophysiology by reducing the collagen content and the stromal SHBG levels and by impairing the AR nuclear import in the epithelial cells. The subsequent epithelial cell apoptosis was responsible for the reduction of the epididymal duct diameter, which, in association with the loss of stroma collagen, contributed to the significant reduction of epididymal weight.

Antiandrogens can act via different mechanisms, such as decreasing androgen synthesis, disrupting pituitary-gonadal axis and/or blocking at least one step of AR action (Georget et al. 2002, Vo et al. 2009). Androgen withdrawal or the antiandrogen cyproterone acetate, for example, impairs the translocation of AR to the nucleus (Tezón et al. 1982, Tyagi et al. 2000, Dar et al. 2014), whereas flutamide impairs the binding of this receptor to DNA (Farla et al. 2005). In the cimetidine-treated rats, the epididymal epithelial cells showed enhanced immunolocalization of AR in the cytoplasm associated with weak/no immunoexpression in the nuclei. These results were supported by Western blot analysis and indicate that cimetidine interferes in the AR nuclear import. It is known that cimetidine competes with testosterone for AR (Funder \& Mercer 1979, Winters et al. 1979, Knigge et al. 1983), and the AR nuclear import depends on DHT binding to AR (Pratt \& Toft 1997, Bennett et al. 2010). Therefore, the failure of the AR to be imported into the nucleus, observed in this study, may be caused by insufficient epithelial androgenization in response to two possibilities: the reduced serum testosterone levels associated to low stromal SHBG levels and/or a direct antagonist effect of cimetidine on the AR (Fig. 8). To clarify this further, a future experiment would be designed to evaluate the immunolocalization of $A R$ in a cimetidine + testosterone group.

The translocation of $A R$ to the nucleus is mediated by karyopherin alpha - KPNA (Cutress et al. 2008), a nuclear import protein specialized in transport of factors involved in cellular differentiation and cancer progression (Okada et al. 2008, Pumroy \& Cingolani 2015). In the cimetidine-treated rat group, the increased AR concentration in the cytoplasm of epithelial cells was concomitant with a reduced KPNA immunoexpression in these cells, reinforcing the failure in the AR nuclear import. Reduced nuclear import has also been related to a decline in KPNA availability in cells following viral infection (Pumroy \& Cingolani 2015). It has been demonstrated that KPNA gene expression is regulated by the Krüppel-like factors (KIf) 2 and 4 (Kamikawa et al. 2011) in mouse embryonic stem cells. Although KIf4 has been shown to be present in the epithelium 


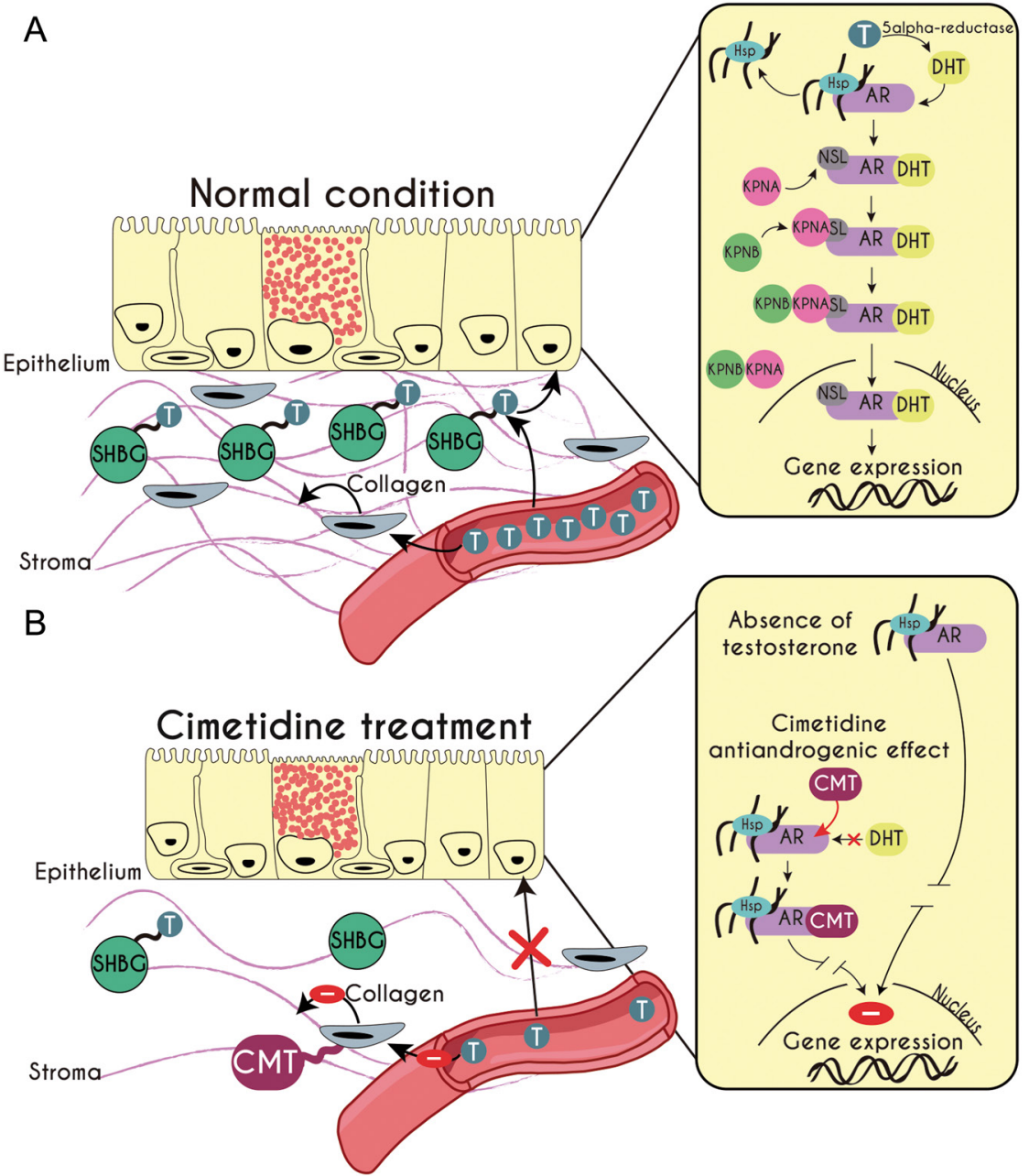

Figure 8 (A and B) Schematic representation of possible mechanisms of cimetidine action in the cauda epididymidis. In (A), under normal condition, testosterone ( $\mathrm{T}$ ) from blood stream may stimulate the collagen production by fibroblasts. The high concentration of SHBG in the stroma may be responsible for the hormonal supply to the epithelium. T binds to SHBG in the stroma and is probably delivered by unclear mechanism to the epithelial cells. In these cells, $\mathrm{T}$ is converted into dihydrotestosterone (DHT) by 5 alphareductase. When DHT binds to androgen receptor (AR), the nuclear localization signal (NSL) is exposed and karyopherin alpha (KPNA) binds to NSL. Karyopherin beta (KPNB) binds to KPNA, and AR + DHT is translocated to the nucleus, stimulating gene expression. In (B), following cimetidine treatment, the stromal atrophy (represented by reduced collagen content) may be caused by low levels of serum $\mathrm{T}$ and/or by a direct antiandrogenic effect of cimetidine on the fibroblasts. The low levels of SHBG in the stroma associated with low levels of T may impair epithelial androgenization. In the epithelial cell, under absence of T, DHT is unavailable and AR is not translocated to the nucleus. Cimetidine may also exert a direct antiandrogenic effect on the epithelial cells, antagonizing AR and preventing AR translocation to the nucleus. of all regions of the epididymis, the role of this protein in this organ has not been clarified (Godmann et al. 2010). However, a recent study has demonstrated that KIf4 gene expression is dependent upon AR activation in androgen-sensitive prostate tumor cell line (Siu et al. 2016). Therefore, further studies need to be designed in attempt to clarify whether the reduced KPNA levels induced by cimetidine may be a result of low Klf4 expression following androgen dysfunction in the epithelial cells.

In the present study, the TUNEL method in association with the ultrastructural features of epithelial cells confirmed the occurrence of apoptosis in these cells, as has also been demonstrated in other cell types (Cerri \& Katchburian 2005). It is known that DHT in the epididymis regulates the expression of genes associated with cell survival, proliferation and growth (Robaire \& Hamzeh 2011). Under androgen withdrawal, all segments of the epididymis undergo apoptosis, leading to a reduction in duct diameter (Fan \& Robaire 1998, Kempinas \& Klinefelter 2014). In the present study, the high apoptotic index induced by cimetidine was coincident with the reduction of epididymal duct diameter. It is known that responses to androgens in androgen-dependent tissues have been associated with AR concentration (Song et al. 1991), as well as decreasing AR levels have been correlated with decreasing testosterone levels after castration (Suzuki et al. 1997). Therefore, the cimetidine-induced high epithelial apoptotic index is related to the AR dysfunction due to a possible deficient androgenic supply to the epithelial cells. This hypothesis is reinforced not only by the interference of cimetidine on the AR nuclear import, but also by the reduction of the total AR levels in the cauda epididymidis.

The reduction in the collagen content of the connective tissue stroma within the cauda epididymidis region reinforces the cimetidine-induced failure in the androgen bioavailability. The synthesis of matrix components, including collagen, is stimulated by androgens in fibroblasts of the prostate (Yu et al. 2012) and the vocal cords (Mukudai et al. 2015). In this study, cimetidine caused significant reduction in serum testosterone levels, as previously demonstrated (Beltrame et al. 2015). Thus, the atrophy of connective tissue observed in this study may be due to reduced serum 
testosterone levels and/or to a direct antiandrogenic effect of this drug on the fibroblasts (Fig. 8). Further studies including a cimetidine+testosterone group would be useful to clarify the mechanism of action of cimetidine on the stroma.

In addition to collagen, stromal SHBG levels were also reduced following cimetidine treatment. SHBG in the blood regulates the bioavailability of sex steroids due to modulation of the non-bound hormone fraction, which is able to diffuse into the target cells (Mendel 1989, Laurent et al. 2016). Extravascular sequestration of SHBG is observed in human reproductive organs (Sinnecker et al. 1988, 1990) and in the stroma of the endometrium and epididymis of transgenic mice expressing human SHBG (Ng et al. 2006). The presence of this protein in these organs points to a function for SHBG beyond the simple regulation of the free fraction of sex steroids because the steroid target cells are not close to the vasculature in these tissues, and the steroid hormone needs to pass through a complex pathway to reach the target cells (Hammond 2002, 2016, Ng et al. 2006). To our knowledge, the present study is the first study demonstrating SHBG in the stroma of adult rat cauda epididymis. Our findings are in accordance with those of previous studies, which demonstrated membrane binding sites for SHBG in cauda epididymidis (Felden et al. 1992, Krupenko et al. 1994) and the presence of this protein in the connective tissue stroma of the Wolffian duct of rat fetuses, where SHBG seems to modulate the action of androgens for the epithelial development (Becchis et al. 1996). Moreover, in the epididymal stroma of transgenic mice expressing human SHBG, this protein is bound to fibulin, an extracellular matrix protein (Ng et al. 2006). Since in the cauda epididymidis the concentration of SHBG in the luminal fluid is low (Robaire \& Hamzeh 2011), the androgenic supply is probably provided by the blood. This is confirmed by the fact that structural changes are not observed in the cauda epididymidis following the blockage of the androgenic supply from testicular fluid by efferent duct ligation (Fan \& Robaire 1998). However, after testosterone withdrawal following orchiectomy, the cauda epididymidis undergoes severe structural changes, which are reversed after restoration of serum testosterone levels (Ezer \& Robaire 2002). Therefore, the immunolocalization of SHBG in the stroma confirms the possible role of this protein in the androgen supply to the epithelium (Fig. 8). Evaluating the immunolocalization of SHBG following orchiectomy and subsequent testosterone replacement would confirm this possibility. The mechanism by which SHBG participates in steroid transport to the epithelial cells has not yet been clarified. Some hypotheses have been proposed, as follows: (1) steroid hormones can dissociate from SHBG and enter into the target cells by passive diffusion (Hammond 2002,
Andreassen 2006); (2) SHBG + steroid is internalized by the cell via receptor mediated endocytosis, as observed in the epididymal initial segment (Gueant et al. 1991, Hermo et al. 1998); (3) SHBG + steroid binds to a membrane receptor and releases the steroid to the cell (Rosner et al. 2010). Considering that endocytosis of SHBG has been observed only in the initial segment of the epididymis (Gueant et al. 1991, Hermo et al. 1998), and that SHBG was not immunolocalized in the epithelium of cauda epididymidis, it is reasonable to suggest that Hypotheses 1 and 3 could explain how androgens reach the epithelial cells in cauda epididymidis. Further molecular studies are necessary to clarify this mechanism.

In the cauda epididymidis, the epithelial cell function and structure are essential to maintain an adequate microenvironment for sperm storage (Robaire \& Hinton 2002). The appropriate $\mathrm{pH}$ contributes to maintain spermatozoa at immotile state (Shum et al. 2011), and the $\mathrm{pH}$ control depends on androgens (Wong \& Yeung 1978, Wong et al. 1978). Moreover, the epithelium secretes proteins that prevent sperm capacitation during storage, and the secretory capacity of epithelial cells is also responsive to androgens (Moore \& Bedford 1979, Koppers et al. 2011). Therefore, the microenvironment that maintains the sperm storage capacity of cauda epididymidis is probably affected following androgen dysfunction induced by cimetidine.

In conclusion, cimetidine treatment induces stromal atrophy in the cauda epididymidis and subsequent reduction of stromal SHBG levels. In the adjacent epithelium, the treatment impaired the AR nuclear import, reduced the levels of KPNA and induced structural changes. These data point to an interference of cimetidine not only on the androgen function, but also on the androgen bioavailability in the cauda epididymidis, reinforcing the possible role of stromal SHBG for the uptake of androgen from the blood stream, and delivery of this steroid to the epithelial cells. These findings support the important role of stromal-epithelial endocrine crosstalk to maintain sperm storage capacity by the cauda epididymidis, and show that cimetidine can be used as a compound to probe the role of androgens in the cauda epididymidis sperm storage region.

\section{Declaration of interest}

The authors declare that there is no conflict of interest that could be perceived as prejudicing the impartiality of the research reported.

\section{Funding}

This work was supported by FAPESP (2012/23845-3; 2013/04870-0; 2015/09341-0). 


\section{Acknowledgements}

We thank Luis Antônio Potenza and Pedro Sérgio Simões for the histological technical assistance. We also thank Priscila Akemi Yamamoto and Cristina Carvalho Barbosa for the assistance with Western blot technique.

\section{References}

Andreassen TK 2006. The role of plasma-binding proteins in the cellular uptake of lipophilic vitamins and steroids. Hormone and Metabolic Research 38 279-290. (https://doi.org/10.1055/s-2006-925348)

Becchis M, Sullivan PM, Ordronneau P, Petrusz P \& Joseph DR 1996. Distribution of immunoreactive androgen-binding protein/sex hormonebinding globulin in tissues of the fetal rat. Steroids 61 392-400. (https:// doi.org/10.1016/0039-128X(96)00049-9)

Beltrame FL \& Sasso-Cerri E 2016. Vitamin $B_{12}$-induced spermatogenesis recovery in cimetidine-treated rats: effect on the spermatogonia number and sperm concentration. Asian Journal of Andrology 18 1-6. (https:// doi.org/10.4103/1008-682X.182397)

Beltrame FL, Caneguim BH, Miraglia SM, Cerri PS \& Sasso-Cerri E 2011. Vitamin $B_{12}$ supplement exerts a beneficial effect on the seminiferous epithelium of cimetidine-treated rats. Cells Tissues Organs 193 184-194. (https://doi.org/10.1159/000319371)

Beltrame FL, Cerri PS \& Sasso-Cerri E 2015. Cimetidine-induced Leydig cell apoptosis and reduced EG-VEGF (PK-1) immunoexpression in rats: evidence for the testicular vasculature atrophy. Reproductive Toxicology 57 50-58. (https://doi.org/10.1016/j.reprotox.2015.05.009)

Beltrame FL, Yamauti CT, Caneguim BH, Cerri PS, Miraglia SM \& SassoCerri E 2012. Cimetidine-induced vascular cell apoptosis impairs testicular microvasculature in adult rats. Histology and Histopathology 27 1343-1351. (https://doi.org/10.14670/HH-27.1343)

Bennett NC, Gardiner RA, Hooper JD, Johnson DW \& Gobe GC 2010. Molecular cell biology of androgen receptor signaling. International Journal of Biochemistry and Cell Biology 42 813-827. (https://doi. org/10.1016/j.biocel.2009.11.013)

Brogden RN, Heel RC, Speight TM \& Avery GS 1978. Cimetidine: a review of its pharmacological properties and therapeutic efficacy in peptic ulcer disease. Drugs 15 93-131. (https://doi.org/10.2165/00003495197815020-00002)

Cerri PS \& Katchburian E 2005. Apoptosis in the epithelial cells of the rests of Malassez of the periodontium of rat molars. Journal of Periodontal Research 40 365-372. (https://doi.org/10.1111/j.1600-0765.2005.00810.x)

Cerri PS \& Sasso-Cerri E 2003. Staining methods applied to glycol methacrylate embedded tissue sections. Micron 34 365-372. (https:// doi.org/10.1016/S0968-4328(03)00098-2)

Chook YM \& Blobel G 2001. Karyopherins and nuclear import. Current Opinion in Structural Biology 11 703-715. (https://doi.org/10.1016/ S0959-440X(01)00264-0)

Clayman CB 1977. Evaluation of cimetidine (tagamet). An antagonist of hydrochloric acid secretion. JAMA 238 1289-1290. (https://doi. org/10.1001/jama.1977.03280130071025)

Clermont Y, Leblond CP \& Messier B 1959. Duration of the cycle of the seminal epithelium of the rat. Archives d'Anatomie Microscopique et de Morphologie Expérimentale 48 (Supplement) 37-55.

Cooper TG 1986. The Epididymis, Sperm Maturation and Fertilization. Berlin: Springer-Verlag.

Cutress ML, Whitaker HC, Mills IG, Stewart M \& Neal DE 2008. Structural basis for the nuclear import of the human androgen receptor. Journal of Cell Science 121 957-968. (https://doi.org/10.1242/jcs.022103)

Dar JA, Eisermann K, Masoodi KZ, Ai J, Wang D, Severance T, SampathKumar SD \& Wang Z 2014. N-terminal domain of the androgen receptor contains a region that can promote cytoplasmic localization. Journal of Steroid Biochemistry and Molecular Biology 139 16-24. (https://doi. org/10.1016/j.jsbmb.2013.09.013)

Domeniconi RF, Souza ACF, Xu B, Washington AM \& Hinton BT 2016. Is the epididymis a series of organs placed side by side? Biology of Reproduction 95 1-8. (https://doi.org/10.1095/biolreprod.116.142240)

EPA - United States Environmental Protection Agency 2006. Harmonization in Interspecies Extrapolation: use of $B W^{3 / 4}$ as default method in derivation of the oral RfD. Washington, D.C.
Ezer N \& Robaire B 2002. Androgenic regulation of the structure and functions of the epididymis. In The Epididymis: From Molecules to Clinical Practice, pp 297-316. Eds B Robaire \& BT Hinton. Boston: Springer US.

Fan X \& Robaire B 1998. Orchidectomy induces a wave of apoptotic cell death in the epididymis. Endocrinology 139 2128-2136. (https://doi. org/10.1210/endo.139.4.5888)

Farla P, Hersmus R, Trapman J \& Houtsmuller AB 2005. Antiandrogens prevent stable DNA-binding of the androgen receptor. Journal of Cell Science 118 4187-4198. (https://doi.org/10.1242/jcs.02546)

Felden F, Leheup B, Fremont S, Bouguerne R, Egloff M, Nicolas JP, Grignon G \& Gueant JL 1992. The plasma membrane of epididymal epithelial cells has a specific receptor which binds to androgen-binding protein and sex steroid-binding protein. Journal of Steroid Biochemistry and Molecular Biology 42 279-285. (https://doi.org/10.1016/09600760(92)90130-B)

Foldesy RG \& Bedford JM 1982. Biology of the scrotum. I. Temperature and androgen as determinants of the sperm storage capacity of the rat cauda epididymidis. Biology of Reproduction 26 673-682. (https://doi. org/10.1095/biolreprod26.4.673)

França LR, Leal MC, Sasso-Cerri E, Vasconcelos A, Debeljuk L \& Russell LD 2000. Cimetidine (Tagamet) is a reproductive toxicant in male rats affecting peritubular cells. Biology of Reproduction 63 1403-1412.

Funder JW \& Mercer JE 1979. Cimetidine, a histamine $\mathrm{H}_{2}$ receptor antagonist, occupies androgen receptors. Journal of Clinical Endocrinology and Metabolism 48 189-191. (https://doi.org/10.1210/ jcem-48-2-189)

Georget V, Térouanne B, Nicolas J-C \& Sultan C 2002. Mechanism of antiandrogen action: key role of hsp90 in conformational change and transcriptional activity of the androgen receptor. Biochemistry $\mathbf{4 1}$ 11824-11831. (https://doi.org/10.1021/bi0259150)

Goda M, Oda K, Oda A, Kobayashi N \& Otsuka M 2017. Involvement of the multidrug and toxic compound extrusion transporter in testosterone release from cultured pig Leydig cells. Pharmacology 100 31-39. (https://doi.org/10.1159/000460822)

Godmann M, Kosan C \& Behr R 2010. Krüppel-like factor 4 is widely expressed in the mouse male and female reproductive tract and responds as an immediate early gene to activation of the protein kinase A in TM4 Sertoli cells. Reproduction 139 771-782. (https://doi.org/10.1530/REP09-0531)

Gueant JL, Fremont S, Felden F, Nicolas JP, Gerard A, Leheup B, Gerard H \& Grignon G 1991. Evidence that androgen-binding protein endocytosis in vitro is receptor mediated in principal cells of the rat epididymis. Journal of Molecular Endocrinology 7 113-122. (https://doi.org/10.1677/ jme.0.0070113)

Hammond GL 2002. Access of reproductive steroids to target tissues. Obstetrics and Gynecology Clinics of North America 29 411-423. (https://doi.org/10.1016/S0889-8545(02)00008-6)

Hammond GL 2011. Diverse roles for sex hormone-binding globulin in reproduction. Biology of Reproduction 85 431-441. (https://doi. org/10.1095/biolreprod.111.092593)

Hammond GL 2016. Plasma steroid-binding proteins: primary gatekeepers of steroid hormone action. Journal of Endocrinology 230 R13-R25. (https://doi.org/10.1530/JOE-16-0070)

Hermo L, Barin K \& Oko R 1998. Androgen binding protein secretion and endocytosis by principal cells in the adult rat epididymis and during postnatal development. Journal of Andrology 19 527-541.

Hinton BT \& Palladino MA 1995. Epididymal epithelium: its contribution to the formation of a luminal fluid microenvironment. Microscopy Research and Technique 30 67-81. (https://doi.org/10.1002/jemt.1070300106)

Kamikawa Y, Yasuhara N \& Yoneda Y 2011. Cell type-specific transcriptional regulation of the gene encoding importin- $\alpha 1$. Experimental Cell Research 317 1970-1978. (https://doi.org/10.1016/j.yexcr.2011.05.024)

Kempinas WG \& Klinefelter GR 2014. Interpreting histopathology in the epididymis. Spermatogenesis 4 e979114. (https://doi.org/10.4161/2156 5562.2014.979114)

Knigge U, Dejgaard A, Wollesen F, Ingerslev O, Bennett P \& Christiansen PM 1983. The acute and long term effect of the $\mathrm{H}_{2}$-receptor antagonists cimetidine and ranitidine on the pituitary-gonadal axis in men. Clinical Endocrinology 18 307-313. (https://doi.org/10.1111/j.1365-2265.1983. tb03216.x)

Koppers AJ, Reddy T \& O'Bryan MK 2011. The role of cysteine-rich secretory proteins in male fertility. Asian Journal of Andrology 13 111-117. (https://doi.org/10.1038/aja.2010.77) 
Koshimizu JY, Beltrame FL, de Pizzol JP, Cerri PS, Caneguim BH \& SassoCerri E 2013. NF-kB overexpression and decreased immunoexpression of AR in the muscular layer is related to structural damages and apoptosis in cimetidine-treated rat vas deferens. Reproductive Biology and Endocrinology 11 29. (https://doi.org/10.1186/1477-7827-11-29)

Krupenko S, Krupenko NI \& Danzo BJ 1994. Interaction of sex sormonebinding globulin with plasma membranes from rat epididymis and other tissues. Journal of Steroid Biochemistry and Molecular Biology 51 115-124. (https://doi.org/10.1016/0960-0760(94)90122-8)

Kubecova M, Kolostova K, Pinterova D, Kacprzak G \& Bobek V 2011. Cimetidine: an anticancer drug? European Journal of Pharmaceutical Sciences 42 439-444. (https://doi.org/10.1016/j.ejps.2011.02.004)

Kumar S, Saradhi M, Chaturvedi NK \& Tyagi RK 2006. Intracellular localization and nucleocytoplasmic trafficking of steroid receptors: an overview. Molecular and Cellular Endocrinology 246 147-156. (https:// doi.org/10.1016/j.mce.2005.11.028)

Laurent MR, Hammond GL, Blokland M, Jardí F, Antonio L, Dubois V, Khalil R, Sterk SS, Gielen E, Decallonne B, et al. 2016. Sex hormonebinding globulin regulation of androgen bioactivity in vivo: validation of the free hormone hypothesis. Scientific Reports 6 35539. (https://doi. org/10.1038/srep35539)

Lim J, Menon V, Bitzer M, Miller LM, Madrid-Aliste C, Weiss LM, Fiser A \& Angeletti RH 2011. Frozen tissue can provide reproducible proteomic results of subcellular fractionation. Analytical Biochemistry 418 78-84. (https://doi.org/10.1016/j.ab.2011.06.045)

Lydka M, Kopera-Sobota I, Kotula-Balak M, Chojnacka K, Zak D \& Bilinska B 2011. Morphological and functional alterations in adult boar epididymis: effects of prenatal and postnatal administration of flutamide. Acta Veterinaria Scandinavica 53 12. (https://doi.org/10.1186/17510147-53-12)

Matsumoto S, Imaeda Y, Umemoto S, Kobayashi K, Suzuki H \& Okamoto T 2002. Cimetidine increases survival of colorectal cancer patients with high levels of sialyl Lewis- $X$ and sialyl Lewis-A epitope expression on tumour cells. British Journal of Cancer 86 161-167. (https://doi. org/10.1038/sj.bjc.6600048)

Mendel CM 1989. The free hormone hypothesis: a physiologically based mathematical model. Endocrine Reviews 10 232-274. (https://doi. org/10.1210/edrv-10-3-232)

Moore HD \& Bedford JM 1979. Short-term effects of androgen withdrawal on the structure of different epithelial cells in the rat epididymis. The Anatomical Record 193 293-311. (https://doi.org/10.1002/ ar.1091930209)

Mukudai S, Matsuda KI, Nishio T, Sugiyama Y, Bando H, Hirota R, Sakaguchi H, Hisa Y \& Kawata M 2015. Differential responses to steroid hormones in fibroblasts from the vocal fold, trachea, and esophagus. Endocrinology 156 1000-1009. (https://doi.org/10.1210/ en.2014-1605)

Ng K-M, Catalano MG, Pinós T, Selva DM, Avvakumov G V., Munell F \& Hammond GL 2006. Evidence that fibulin family members contribute to the steroid-dependent extravascular sequestration of sex hormonebinding globulin. Journal of Biological Chemistry 281 15853-15861. (https://doi.org/10.1074/jbc.M512370200)

Nybo K 2012. Non-specific antibody interactions. BioTechniques 52 305-306.

Okada N, Ishigami Y, Suzuki T, Kaneko A, Yasui K, Fukutomi R \& Isemura $\mathbf{M}$ 2008. Importins and exportins in cellular differentiation. Journal of Cellular and Molecular Medicine 12 1863-1871. (https://doi. org/10.1111/j.1582-4934.2008.00437.x)

Orgebin-Crist MC, Danzo BJ \& Davies J 1975. Endocrine control of the development and maintenance of sperm fertilizing ability in the epididymis. In Male Reproductive System, edn 1, 319-338. Eds RO Greep \& DW Hamilton. Washington, D.C.: American Physiological Society.

Pratt WB \& Toft DO 1997. Steroid Receptor Interactions with Heat Shock Protein and Immunophilin Chaperones 1. Endocrine Reviews 18 306-360.

Pumroy RA \& Cingolani G 2015. Diversification of importin- $\alpha$ isoforms in cellular trafficking and disease states. Biochemical Journal 466 13-28. (https://doi.org/10.1042/BJ20141186)

Reid BL \& Cleland K 1957. The structure and function of the Epididymis. 1. The histology of the rat Epididymis. Australian Journal of Zoology 5 223-246. (https://doi.org/10.1071/ZO9570223)
Robaire B \& Hamzeh M 2011. Androgen Action in the Epididymis. Journal of Andrology 32 592-599. (https://doi.org/10.2164/ jandrol.111.014266)

Robaire B \& Hermo L 1988. Efferent Ducts, epididymis and vas deferens: structure, functions, and their regulation. In The Physiology of Reproduction, edn 1, 999-1080. Eds E Knobil \& J Neill. New York: Raven Press.

Robaire B \& Hinton BT 2002. The Epididymis: From Molecules to Clinical Practice: A Comprehensive Survey of the Efferent Ducts, the Epididymis, and the Vas Deferens. New York: Springer.

Rosner W, Hryb DJ, Kahn SM, Nakhla AM \& Romas NA 2010. Interactions of sex hormone-binding globulin with target cells. Molecular and Cellular Endocrinology $316 \quad 79-85 . \quad$ (https://doi.org/10.1016/j. mce.2009.08.009)

Sasso-Cerri E \& Cerri PS 2008. Morphological evidences indicate that the interference of cimetidine on the peritubular components is responsible for detachment and apoptosis of Sertoli cells. Reproductive Biology and Endocrinology 6 1-10. (https://doi.org/10.1186/14777827-6-1)

Sasso-Cerri E \& Miraglia SM 2002. In situ demonstration of both TUNELlabeled germ cell and Sertoli cell in the cimetidine-treated rats. Histology and Histopathology 17 411-417. (https;//doi.org/10.14670/ $\mathrm{HH}-17.411)$

Shum W C, Ruan Y C, Da Silva N \& Breton S 2011. Establishment of cell-cell cross talk in the epididymis: control of luminal acidification. Journal of Andrology 32 576-586. (https://doi.org/10.2164/ jandrol.111.012971)

Sinnecker G, Hiort O, Kwan PW \& DeLellis R 1990. Immunohistochemical Localization of sex hormone-binding globulin in normal and neoplastic breast tissue. Hormone and Metabolic Research 22 47-50. (https://doi. org/10.1055/s-2007-1004847)

Sinnecker G, Hiort O, Mitze M, Donn F \& Neumann S 1988. Immunohistochemical detection of a sex hormone binding globulin like antigen in tissue sections of normal human prostate, benign prostatic hypertrophy and normal human endometrium. Steroids 52 335-336. (https://doi.org/10.1016/0039-128X(88)90134-1)

Siu M-K, Suau F, Chen W-Y, Tsai Y-C, Tsai H-Y, Yeh H-L \& Liu Y-N 2016. KLF4 functions as an activator of the androgen receptor through reciprocal feedback. Oncogenesis 5 e282. (https://doi.org/10.1038/ oncsis.2016.79)

Song CS, Rao TR, Demyan WF, Mancini MA, Chatterjee B, Roy AK 1991. Androgen receptor messenger ribonucleic acid (mRNA) in the rat liver: changes in mRNA levels during maturation, aging, and calorie restriction. Endocrinology 128 349-356. (https://doi.org/10.1210/endo128-1-349)

Spence RW \& Celestin LR 1979. Gynaecomastia associated with cimetidine. Gut 20 154-157. (https://doi.org/10.1136/gut.20.2.154)

Suzuki K, Ito K, Kurokawa K, Suzuki T, Shimizu N, Fukabori Y, Honma S \& Yamanaka H 1997. Expression and degradation of rat androgen receptor following castration, testosterone replacement and antiandrogens administration: analysis by Western blot and immunohistochemistry. Tohoku Journal of Experimental Medicine 183 159-172. (https://doi. org/10.1620/tjem.183.159)

Tezón JG, Vazquez MH \& Blaquier JA 1982. Androgen-controlled subcellular distribution of its receptor in the rat epididymis: 5 alphadihydrotestosterone-induced translocation is blocked by antiandrogens. Endocrinology 111 2039-2045.

Tsuji L, Takumi T, Imamoto N \& Yoneda Y 1997. Identification of novel homologues of mouse importin $\alpha$, the $\alpha$ subunit of the nuclear poretargeting complex, and their tissue-specific expression. FEBS Letters 416 30-34. (https://doi.org/10.1016/S0014-5793(97)01092-2)

Tyagi RK, Lavrovsky Y, Ahn SC, Song CS, Chatterjee B \& Roy AK 2000. Dynamics of intracellular movement and nucleocytoplasmic recycling of the ligand-activated androgen receptor in living cells. Molecular Endocrinology 14 1162-1174. (https://doi.org/10.1210/ mend.14.8.0497)

Van Thiel DH, Gavaler JS, Heyl A \& Susen B 1987. An evaluation of the antiandrogen effects associated with $\mathrm{H} 2$ antagonist therapy. Scandinavian Journal of Gastroenterology 136 24-28.

Vo TTB, Jung E-M, Dang VH, Jung K, Baek J, Choi K-C \& Jeung E-B 2009. Differential effects of flutamide and di-(2-ethylhexyl) phthalate on 
male reproductive organs in a rat model. Journal of Reproduction and Development 55 400-411. (https://doi.org/10.1262/jrd.20220)

Wang C, Lai CL, Lam KC \& Yeung KK 1982. Effect of cimetidine on gonadal function in man. British Journal of Clinical Pharmacology 13 791-794. (https://doi.org/10.1111/j.1365-2125.1982.tb01867.x)

Winters SJ, Banks JL \& Loriaux DL 1979. Cimetidine is an antiandrogen in the rat. Gastroenterology 76 504-508.

Wong PY \& Yeung CH 1978. Absorptive and secretory functions of the perfused rat cauda epididymidis. Journal of Physiology 275 13-26. (https://doi.org/10.1113/jphysiol.1978.sp012174)

Wong PYD, Au CL \& Ngai HK 1978. Electrolyte and water transport in rat epididymis; its possible role in sperm maturation. International Journal of Andrology 1 608-628. (https://doi.org/10.1111/j.1365-2605.1978. tb00512.x)
Yu S, Yeh C-R, Niu Y, Chang H-C, Tsai Y-C, Moses HL, Shyr C-R, Chang C \& Yeh S 2012. Altered prostate epithelial development in mice lacking the androgen receptor in stromal fibroblasts. The Prostate 72 437-449. (https://doi.org/10.1002/pros.21445)

Received 6 January 2018

First decision 6 February 2018

Revised manuscript received 11 March 2018

Accepted 29 April 2018 